\title{
永久気管孔狭窄への対処
}

\author{
市 村 恵 一*, 加 瀬 康 弘* \\ 山根 雅 昭*, 田中 利善**
}

\section{How to Deal with Stenosis of Tracheostoma?}

\author{
Keiichi Ichimura, M.D., ${ }^{*}$ Yasuhiro Kase, M.D., ${ }^{* *}$ \\ Masaaki Yamane, M.D., ${ }^{*}$ and Toshiyoshi Tanaka, M.D. ${ }^{* *}$ \\ *Department of Otolaryngology, Tokyo University Branch Hospital, Tokyo, and \\ **Division of Otolaryngology, Social Insurance Central General Hospital, Tokyo
}

We have treated 6 patients with tracheostomal stenosis for the last 5 years. Permanent tracheostomata were created during total laryngectomy in 5 adult patients, and during laryngotracheal separation in a pediatric patient with congenital multiform arthrogryposis. In most cases, stenosis occurred in a month or two after the surgery, while it developed when systemic skin rash occurred in 2 patients whose stomal size had been stable for a fairly long time.

Stomal stenosis can be defined as a scar contracture developed along a circular suture line. Therefore the surgical strategy against the stenosis of stoma should be the same as that of general scar formation in the skin. Taking this into account, the two following policies can be selected: One is Z-plasty and its modification or transposition of local flaps only to reposition and relax the line of contracture. The other is a complete removal of the cicatrical tissues to eradicate the lesion. If any contributing factors to stenosis remain, the choice should be the former. Therefore, we have employed the interposition of four paired triangular flaps regardless of stomal configuration. However, there seems to be no satisfactory solution at present against stomal stenosis due to hypertrophic scars or keloids. Systemic approach considering precipitating factors of stenosis is essential.

An ideal stoma does not necessarily mean a wide one. Patients in this study have insisted the adequate size of $14-20 \mathrm{~mm}$ vertically and $12-18 \mathrm{~mm}$ horizontally, which is almost the same diameter as the trachea. The critical size where every adult patient has complained to be dyspneic was less than $10 \mathrm{~mm} \times 8 \mathrm{~mm}$.

Key words : tracheostoma, stomal stenosis, scar contracture, reconstruction

*東京大学医学部付属病院分院耳鼻咽喉科, **社会保 険中央総合病院耳鼻咽喉科

別刷請求： $=112$ 東京都文京区目白台3-28-6 東京大学医学部付属病院分院耳鼻咽喉科 市村恵一

投稿受付：1990年10月17日

\section{I . 緒 言}

喉頭摘出術を行った際には永久気管孔が作製 されるが，その中で少数ではあるものの狭窄が 起こる場合がある。気管孔の狭窄が起こると, 換気の障害のみならず粘液の停滞が起こり，下 気道感染を引き起こしやすくなるうえに，痂皮 がつきやすくなり，それが窒息の原因にもなる 
ので絶対に矯正すべき病態である1)。狭窄傾向 が出たときには喉頭摘出時用のカニューレを一 定期間留置することで対処し得る例もあるが, その多くは手術的に対処せねばならないもので ある。

従来の気管孔狭窄に対する手術の報告は, 初 めてこの問題を取り上げたConverse ${ }^{2)}$ 以来, 成 功例の紹介に終始しており，何回も再発を繰り 返す厄介な例についての検討が行われているも のは少ない。そこでわれわれが最近経験した狭 窄手術例のうち，とくに再度開大を行わねばな らなかったものを中心に呈示してみたい。また， 術後当分の間は気管孔が大きく開いていなが ら, 後になって狭くなり出す例に抢いて, 従来 は指摘のなかった皮膚疾患の合併があることが わかったので, 病変の本態からみた手術法の選 択についての検討とあわせて考察したい。

\section{II. 対 象}

最近 5 年間に永久気管孔が狭窄し，その開大 を行う必要のあった症例を 6 例経験した（表 1)。この数はそれ以前に比べ激増しているが, 喉頭摘出例数の増加によるものではない。症例 1 は他院での術後であり, 他の 5 例は当院, あ るいは関連病院で筆者らが施行した術後例であ る。当院では気管孔の形成に際し, 特に統一し た方法は決めておらず，各術者の裁量に任され ているが, 各年次で術者の経験年数による構成 が著しく異なることはない。

5 例の高年齢の症例は喉頭癌で喉頭摘出を行 ったための, 症例 6 の小児例は多発性関節拘縮 とそれに関連する病変のための誤嬩により喉頭 気管分離術に伴う永久気管孔造設である。基礎
疾患として，糖㽷病，スモン，アルコール性肝 障害, 肥満, 多発性関節拘縮などがあった。放 射線照射や頸部郭清術の有無もさまざまであっ た。なお男女比は $2: 4$ で, 従来の報告で男子に 多いという結果と異なり,女子が優位であった。 狭窄例の多くが気管孔を形成した時点，ある いは 1 力月以内に狭窄傾向を示しているのに対 し，気管孔形成後長期間広さが保たれていたも のの, ある時期を境にして狭窄が起こった例も 存在した。その原因として皮膚疾患の存在が考 えられた。症例 3 は 1 年以上適切な大きさの気 管孔をもつて経過したが，丘疹が全身に出てか ら急速に気管孔周囲が瘢痕性に狭くなり始め, 症例 6 は丘疹性紅斑の出現と同時に狭くなり始 めた。これらは後で詳しく述べる。また症例 5 では術創の感染が起こったため, 形成時には十 分大きかった気管孔が狭窄した。

症例 4 は胸鎖乳突筋と切断部が高すぎた前頸 筋群断端を巻き込んだ形で狭窄が起こった。

狭窄の型は中心狭窄型 3 名, 縦裂型 3 名であ った(表 2$)$ 。6 名中 3 名は 2 回以上の手術を要 しており, 採用した手術法の主なものはfourpaired triangular flap ${ }^{3)}$ ( 4 対三角弁法), fishmouth 法4,5), Montgomery による外側に基部を もつ皮弁を孔の両側につくる方法6) (trap-door

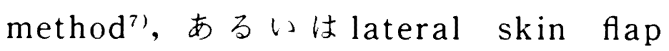
technique $^{8)}$ として紹介されている) などであっ た。

術後の気管孔の大きさを経過でみた（表 3 )。 多くは術後早期から小さくなる傾向を見せてお り，10×8 mm 位を境に症状として呼吸困難が 現われている。カニューレを插入して狭窄を予 防した例もあるが, 症例 3 のようにカニューレ

表 1 気管孔狭窄症例とその背景

\begin{tabular}{|c|c|c|c|c|c|c|}
\hline 症例 & 年齢 & 性 & 喉摘 $\rightarrow$ 狭窄 & 頸郭 & 照射 & 基礎疾患 \\
\hline 1 & 79 & $\mathrm{~F}$ & 21年 & - & ? & スモン \\
\hline 2 & 53 & $\mathrm{~F}$ & 1 力月 & - & 40 Gy (術前) & 糖尿病 \\
\hline 3 & 56 & $\mathrm{~F}$ & 20力月 & + & - & 肥満 \\
\hline 4 & 79 & $\mathrm{~F}$ & 1 力月 & - & $\begin{array}{l}70 \mathrm{~Gy} \text { (9Y 前) } \\
60 \mathrm{~Gy} \text { (4 Y 前) }\end{array}$ & - \\
\hline 5 & 65 & M & 2 力月 & + & - & 肝障害 \\
\hline 6 & 4 & M & 1 力月 & - & - & $\begin{array}{c}\text { 多発性関節拘縮 } \\
\text { 気管脆弱 }\end{array}$ \\
\hline
\end{tabular}


表 2 気管孔狭窄症例の成立原因, 型, 手術治療

術回数は気管孔開大術の回数, 手術法は本文参照。

\begin{tabular}{|c|c|c|c|l|}
\hline 症例 & 原 因 & \multicolumn{1}{|c|}{ 型 } & 術回数 & \multicolumn{1}{|c|}{ 開 大 法 } \\
\hline 1 & 不明 & 縦裂 & 1 & 4 対三角弁 \\
2 & 形成法の拙劣 & 中心 & 2 & Y 形成, 4 対三角弁 \\
3 & 丘疹性皮䖉病変 & 中心 & 5 & 4 対三角弁 3, fish mouth \\
& & & & Donegan-Silver \\
4 & 筋の引き込み & 縦裂 & 2 & trap door+三角弁, trap door \\
5 & 術創感染 & 縦裂 & 1 & trap door \\
6 & 気管脆弱 & 中心 & 1 & 4 対三角弁 \\
& 発疹性皮膚疾患 & & & \\
\hline
\end{tabular}

表 3 気管孔の大きさの推移

各症例の最初の行は永久気管孔作製から狭窄発生までの経過, 2 行目以降は気管孔 開大以後の経過を示す。太字は息苦しさを訴えている状態での大きさ。 * : 気管カニューレ留置。単位は $\mathrm{mm}$ 。

\begin{tabular}{|c|c|c|c|c|c|c|c|c|}
\hline 症例 & \multicolumn{3}{|c|}{2} & \multicolumn{5}{|c|}{3} \\
\hline 術後 1 月 & $11 \times 9$ & $12 \times 9$ & $14 \times 12$ & $22 \times 20$ & $18 \times 15$ & $17 \times 12$ & & $25 \times 17$ \\
\hline 2 & $10 \times 8$ & & & & $9 \times 9$ & $13 \times 11$ & $18 \times 15$ & $17 \times 14$ \\
\hline 3 & & $9 \times 8$ & $13 \times 10$ & & $9 \times 7$ & $12 \times 9$ & $13 \times 10$ & $10 \times 7$ \\
\hline 6 & $8 \times 7$ & $10 \times 8$ & $14 \times 10$ & $20 \times 18$ & & $(10 \times 8)$ & $(10 \times 7)$ & \\
\hline 12 & & $10 \times 6$ & $14 \times 10$ & $18 \times 17$ & & $4 \mathrm{M} 0$ & $4 \mathrm{M} 0$ & \\
\hline 18 & & $8 \times 6$ & & $10 \times 8$ & & & & \\
\hline 症例 & \multicolumn{3}{|c|}{4} & \multicolumn{2}{|c|}{5} & \multicolumn{3}{|c|}{6} \\
\hline 術後 1 月 & $12 \times 7$ & $14 \times 8$ & $14 \times 11^{*}$ & $12 \times 6$ & $20 \times 12$ & $13 \times 8$ & \multicolumn{2}{|l|}{$9 \times 8^{*}$} \\
\hline 2 & $10 \times 4$ & $12 \times 7$ & $16 \times 11$ & $10 \times 4$ & $14 \times 13$ & $(4 \times 4)$ & \multirow{3}{*}{\multicolumn{2}{|c|}{$7 \times 7$}} \\
\hline 3 & & $10 \times 6$ & $16 \times 11$ & $11 \times 4$ & $16 \times 11$ & 1 週後 & & \\
\hline 6 & & & $19 \times 12$ & & $16 \times 12$ & & & \\
\hline
\end{tabular}

の留置は刺激になるのでいやだと拒否し，開大 術を反復した例もあった。

\section{III．皮膚疾患の発生が狭窄の引き金となった と思われる症例}

\section{症例 3 : 56歳, 女子}

1987年11月11日に声門上部喉頭癌（T3N1 M0)のため, 喉頭全摘出術と左側根治的頸部郭 清術を受けた。術後 ${ }^{60} \mathrm{Co}$ を $50 \mathrm{~Gy}$ 照射してい る。気管孔は大きく問題はなかったが，88年 7 月に全身に丘疹が出現した。この時期には 5$\mathrm{FU}$ を内服していたが, 中止しても軽快せず, 薬 物との因果関係はないものと思われた。皮膚科 で治療するも抵抗性で, 完治には 1 年以上を要 した。
この丘疹発現から徐々に気管孔が狭窄し始 め, 1 年後には瘢痕性に中心性狭窄が完成し, 歩行時に息切れが生じるようになった。89年 7 月22日に気管孔開大術を 4 対三角弁法で行っ た。この際は三角弁のトリミングだけで䑤痕組 織は除去しなかった。 2 力月間は良好な大きさ を保ったが，10月からケロイド状となり急に狭 窄してきたため，11月 1 日に同じ方法で再手術 した。

リザベン®を投与し，過利瘷痕の予防を試み たが，それでも少しずつ狭窄が進行し，翌年 4 月11日に再手術となった。今度は痒痕組織を除 去してみることとし，fish-mouth 法を採用した が，それでもまた 3 力月を過ぎる頃から狭窄が 始まった。8月15日には Donegan-Silver 法9) 
を用い，心臓型に周囲瘢痕皮膚組織を大きく切 除した上で気管後壁に切開を加え, 皮弁を介在 させ形成した。

術後はセルテクト®を服用させ，過剩疲痕形 成の防止をはかったが, 結局再狭窄を起こした ので，11月14日に 4 対三角弁法で洀痕組織を除 去せずに拡大した後，予防的に気管カニューレ を装用しない限りどんな方法を採用しても制御 しきれないであろうと説得し，装用させた。そ の後経過観察中である。

\section{症例 6：4 歳, 男子}

出生時より arthrogryposis multiforme congenita (先天性多発性関節拘縮症) で一定体位し かとれず，嚥下が不能で，長期間気管切開孔よ りカニューレが留置されていたが, 気管切開孔 周囲やカニューレ先端に肉芽を形成するため, 切除を反復していた。また気管自体も脆弱であ つた。長期間管理の面から1990年 3 月14日に喉 頭気管分離術を行った。

気管は第 2,3 軟骨間で分離し, 頭側端は食 道前面に形成した孔と端側吻合し, 尾側端は永 久気管孔とした。気管孔は術後 3 週間まではカ ニューレも插入せず一定の大きさを保ってい た。4月6日急に全身の紅斑（丘疹状）が出現 し，1 週間で急速に狭小化した。当初は腸㾞よ り注入し始めたエンシュアリキッド、に対する 過敏症が疑われたが, 否定され, ウイルス性の
ものと推定された。

カニューレの留置で様子をみたが，それを除 去すると直ちに孔が狭くなるので，5月17日 4 対三角弁法による開大術を施行したうえで，力 ニューレの先端を $3 / 4$ ほど切除したものを予防 的に留置し経過観察中である。

\section{IV. 考 察}

狭窄をその形から分類すると，その多くは中 心狭窄型（全周にわたって求心性に狭窄するも の）と，縦裂型（上下方向でスリット状に狭窄 がくるもの）で占められる。この他に少ないな がら下方棚型や上方ひさし型, 漏斗型といった タイプもある(図 1)。これらはまとめると瘢痕 性といえるが，これに対し，気管壁そのものの 軟弱さに起因する狭窄も存在する7)。

多数例を集めたYonkersらの論文によると， 緹裂型は胸鎖乳突筋の引き込まれによるものが 多く，照射や炎症によるもの，気管径の狭いも の, 手術手技に起因するものは中心狭窄型をつ くりやすいという4。。そして頻度では後者の方 が倍以上多い4)が，飯田らの経験では10例中 9 例を縦裂型が占めている10)。

そこではYonkersらが中心狭窄型を起こし やすいとしたさまざまな原因でも縦裂型狭窄を 起こしている。この差についてはわれわれも経 験数が多くないので論評は避けるが, 概して皮 䖉組織痽痕の過剰な場合は中心型, 皮膚や他の
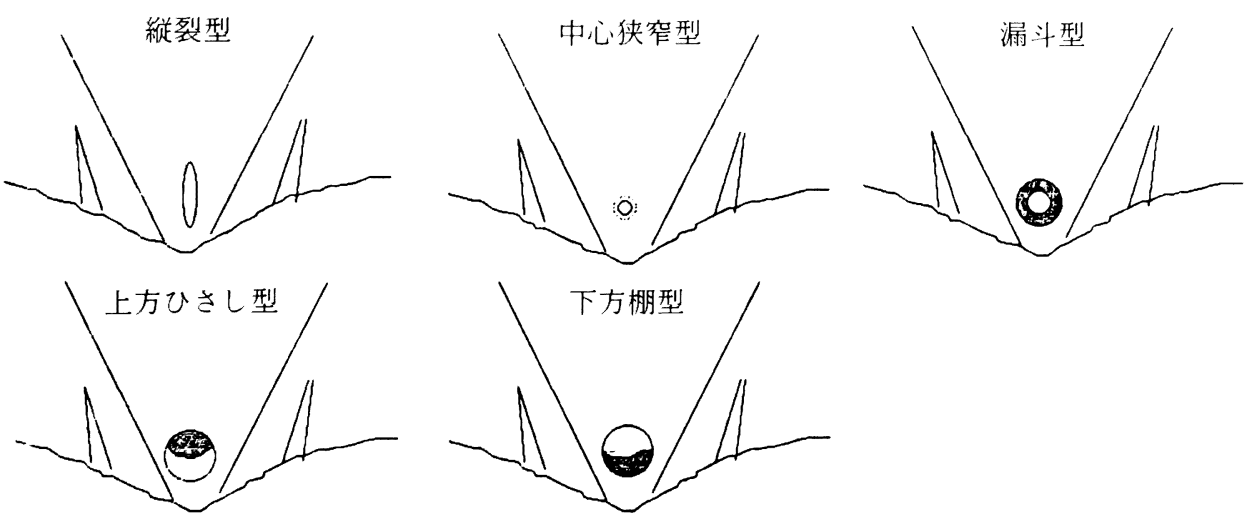

図 1 気管孔狭窄の形態別分類 ここに掲げた瘢痕性狭窄以外に気管壁の脆弱性に起因する軟弱型が存在する。 
表 4 気管孔狭窄の原因

- 過剩洀痕形成: 感染, 瘻孔

- 照射の影響，基礎疾患

・ケロイド

- 脂肪過咶, 皮膚過㮃

- 腫大甲状腺

- 胸鎖乳突筋, 前頸筋群のかぶさり

-手術手技の失敗：縫合不良，軟骨断端露出 不適切な気管切除

一術後管理のまずさ：抜采の早すぎ，系の内部遺残

・気管発育不良

- 腫瘍再発

組織の余利や皮虞以外の組織の瘢痕化や脱落に よる場合は縦裂型をとるように思われる。今回 強調した皮膚病変を契機に狭窄した場合は中心 狭窄型をとっている。

他の病態上同様に，気管孔狭窄においても予 防が最良の治療法である。表 4 に示したような, 狭窄が起こる諸原因を除去することで予防を図 るのが好ましい。いったんでき上がった痽痕性 狭窄を治すには，手術以外に適切な方法はない といえるが，気管孔開大術として報告されてい る術式はきわめて多く，標準とされるものがな い状況である。

このことは，どういう術式を考えても形成外 科的常識にかなうものならば十分役立つともい えるし, 逆に比類なく優れたものがない状況を 示唆するともいえる。腫瘍の専門施設に在籍す る医師でない限り，各人がそれほど多くこの手 術を経験するわけではないので，いくつかの方 法に慣れるのがせいぜいで，多くの術式を試み る余裕はないのが実情であろうと思われるだけ に, 状態に応じた標準的方法の確立が望まれる。

中心狭窄型に対する手術法として報告されて いる方法の多くは, 瘢痕組織を十分除去し, 気 管輪を露出させ，牽引挙上した気管の粘膜を皮 膚と縫合する方法である。しかし, 痏痕を過剩 に切除すると血行障害をきたし, 再瘢痕化の原 因となることもあるといわれる ${ }^{11}$ 。中心性狭窄 の場合は円周状の 1 本の縫合線に基づく瘦痕収 縮による狭窄とみなしうるので，その修正には 直線の縫合線を避け，ジグザグの縫合線にする のがよい12)。そうした点ではZ形成(ただし $1 つ$
のみでは十分広がらないので複数置く必要があ る ${ }^{13)}$ ) か, Bernstein が提唱した 4 対三角弁法3) を用いるのが好ましく，筆者は後者を好んで用 いている。

松島らが報告している方法 ${ }^{14)}$ も後方を残し た 3 対三角弁法で, これと同類のものと思われ る。この方法の実際はすでに報告した ${ }^{15)}$ が, 疫 痕組織をあえて除去しなくても拡大が可能な点 で有利であり，また状況に応じて疲痕組織を除 去することもできる。この方法はきわめて確実 な方法で, 症例 3 を除いては筆者が従来から経 験した全例において 1 回の開大手術のみで済ん でおり，以後狭窄を経験していないが，症例 3 のみは 2 回試みたが失敗している。この例では 周囲皮覤の瘢痕化が異常ともいえるように進 み, 結局周囲皮膚を大きく切除する方法を行わ ねばならなかった。しかし，その方法といえど も一度は再狭窄を起こし, 現在は経過観察中で あるので，最終的な判定はできていない。

繰り返すが，気管孔狭窄が円周上の 1 本の縫 合線の瘢痕収縮であるという本質を見直すなら ば，皮膚上の瘢痕を形成する場合と手術方針が 同じになることは理解できよう。その場合, 痽 痕を切除した後, 十分に皮下を剥離し, 皮膚断 端同士を引っ張り縫合するのか, Z 形成を行っ て緊張を取ると同時に目立たなくするのか，が 方針の分かれ目になる。基本的に再痒痕を生ま ない条件が整っているなら前者が優れていよ う。しかし，いわゆるケロイド体質をはじめと し, 再狭窄の要因が残存するなら後者の方が採 用されるべきである。

Trailらが, 過剰瘢痕やケロイドに対しては 満足な治療法がない16) と述べた状況は20年を 経た現在でも変わっておらず，抗アレルギー剂 がケロイド防止作用があるといわれているもの の, 画期的な効果はない。先に述べた皮膚病変 が狭窄を誘発してくる可能性も考慮すれば, 狭 窄に関連する全身的な因子をさらに検討するこ と, 加えてそれらに対する治療法を模索してい く必要があろう。

縦裂型狭窄に対しては，牽引のみに頼る方法 は再狭窄に宿りやすく, 気管に切開線を加えて 広げ，何らかの形で皮弁を介在させる方法が好 ましい。 4 対三角弁法を用いても目的を達する 
が, fish mouth 法 ${ }^{4.5)}$ が, この型には適切である と思われる。この方法は元来が喉頭摘出時に永 久気管孔を作製する際に大きなものを作るため

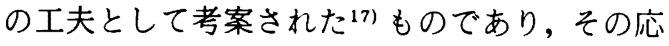
用である。この場合は周囲の瘢痕組織を除去し, 気管を引き出し, 割を加えた後, 皮弁を介在さ せる操作が必要になる。

気管孔は広ければ広いほどよいわけでもな く，適切な大きさがあることも銘記したい。縦 で15〜20 mm, 横で12〜18 mm くらいが今回の 成人患者の訴える適切な大きさであった。

\section{V.まとめ}

6 症例の気管孔狭窄症例に対する検討を行っ た。永久気管孔を形成し 1 力月以内から狭窄が 明らかになったものが多い中で，後になって狭 窄が出現するもので, 皮膚病変が関与したと思 われる症例があった。

中心性狭窄例に対しては瘢痕を除去せずに開 大する方法が，また縋裂型の狭窄には気管壁を 割って皮弁を介在させる方法で対処しておおむ ね良好な結果を得たが，現在のところ，過剩痽 痕に起因すると思われる症例に対する絶対的な 方法は見あたらず，今後は全身的配慮も必要と なろう。

本論文の要旨は第42回日本気管食道科学会学術講 演会において報告した。

\section{文献}

1) Balle, V.H., and Bretlau, P.: Tracheostomal stenosis following total laryngectomy. J. Laryngol. Otol., $99: 577-580,1985$.

2 ) Converse, J.M. : An operation for relief of stenosis of the stoma following total laryngectomy. Arch. Otolaryngol., 52 : 950-951, 1950.
3 ) Bernstein, L. : Z-plasty in head and neck surgery. Arch. Otolaryngol., 89 : 574-584, 1969.

4 ) Yonkers, A.J., and Mercurio, G.A.: Tracheostomal stenosis following total laryngectomy. Otolaryngol. Clin. North. Am., 16:391-405, 1983.

5 ) Panje, W.R., and Kitt, V.V. : Tracheal stoma reconstruction. Arch. Otolaryngol., 111 : 190192, 1985.

6 ) Montgomery, W.W.: Stenosis of tracheostoma. Arch. Otolaryngol., 75 : 76-79, 1962.

7 ) Meyer, R.: Reconstructive Surgery of the Trachea, pp. 120-121, Georg Thieme Verlag, Stuttgart-New York, 1982.

8 ) Lore, J.M.: Correction of tracheal stoma stenosis. In "An Atlas of Head and Neck Surgery (Lore, J.M., ed.)” 3rd Ed., pp. 930-931, W.B. Saunders, Philadelphia, 1988.

9 ) Donegan, J.O., and Silver, F. : Correction of tracheal stomal stenosis. Laryngoscope, 94 : 977-979, 1984.

10）飯田 賞, 細井裕司, 木村裕毅 - 他：喉摘後の 気管孔狭窄症例の臨床的観察および気管孔開大 手術法。日気食会報，41：47-56, 1990 。

11）加藤 功, 菱沼文彦, 細川 智 -他: 気管孔狭 窄に対する新しい手術法. 手術, 30：1137-1140, 1976.

12）原科孝雄, 掛川暉夫：Z plastyに上る狭窄永久 気管孔形成術。手術，33：969-973, 1979.

13) Weaver, A.W. : Modified Y-plasty procedure for tracheal stoma revision. Surg. Gynec. Obst., 125：601-602, 1967.

14）松島四郎, 浜之上隆史, 西憲一郎: 気切孔拡大 術における狭窄防止の一工夫. 日耳鼻, $87 ： 229$, 1983.

15）市村恵一：気管孔狭窄開大術. JOHNS，6： 1139-1142, 1990.

16) Trail, M.L., Chambers, R., and Leonard, J.R. : $Z$-plasty of tracheal stoma at laryngectomy. Arch. Otolaryngol., 88:110-112, 1968.

17) Catlin, D.: Making a large tracheal stoma during laryngectomy. EENT Month, $45: 87-$ $90,1966$. 